\title{
Studentska procjena važnosti usvajanja pravilnoga izgovora u mađarskom kao stranom jeziku
}

\author{
Kristina Katalinić \\ kkatalin@ffzg.hr \\ Filozofski fakultet Sveučilišta u Zagrebu
}

\begin{abstract}
Poučavanje i usvajanje dobroga izgovora na filološkim studijima ponajviše ovisi o samom studijskom programu, broju sati predviđenih za jezične vježbe i druge jezikoslovne kolegije, kao i o kompetentnosti nastavnika koji taj studijski program izvode. Ovim se radom želi prikazati koliko se uz prenošenje teorijskih znanja u programu studija hungarologije na Filozofskom fakultetu u Zagrebu provode praktične vježbe na dobrom izgovoru, u okviru kojih kolegija i na koji način. Nadalje, dat će se kratka usporedba mađarskoga i hrvatskoga fonološkog sustava s naglaskom na elementima koji za odrasle početnike predstavljaju poteškoće u usvajanju izgovora. U trećem dijelu rada iznijet će se rezultati provedenoga istraživanja među studentima hungarologije kojim se iz njihove perspektive željela ispitati važnost pravilnoga izgovora u usvajanju mađarskoga kao stranog jezika kako bi se dobile moguće smjernice za poboljšanja postojećega i izradu novoga studijskog programa.
\end{abstract}

Ključne riječi: govorna produkcija, izgovorna odstupanja, mađarski kao J2, poučavanje i usvajanje izgovora, samoprocjena. 


\section{UVOD}

Jedan od ciljeva poučavanja stranih jezika na filološkim studijima jest osoposobiti studente za tečnu i razumljivu govornu produkciju koja je preduvjet uspješne komunikacije ${ }^{1} \mathrm{u}$ različitim životnim situacijama. Takva govorna produkcija osim primjene gramatičkih pravila i naučenoga leksičkog materijala, uključuje i ono što je u stranom jeziku možda i najteže usvojivo, a to je pravilan izgovor (Bóna, 2017: 217). Pravilan izgovor u prvom se redu odnosi na pravilnu artikulaciju glasova, a potom i na naglasak, rečeničnu intonaciju, tempo, ritam i pauze, dakle segmentalne i suprasegmentalne (prozodijske) elemente jezika. Na važnu ulogu pravilnoga izgovora upućuje i pojava kada izvorni govornici gramatički nepravilne, ali fonetski točne iskaze često percipiraju lakše i točnije od iskaza koji su gramatički pravilni, ali fonetski iskrivljeni (Kassai, 1995: 103). Kada govorimo o iskrivljenom izgovoru ili greškama u izgovoru, mislimo zapravo na izgovorne specifičnosti neizvornoga govornika koje se javljaju kao otkloni od norme i nazivamo ih akcentom, a nastaju tako što učeći strani jezik pokrećemo i upotrebljavamo artikulacijsku i percepcijsku bazu materinskoga jezika pa dolazi do interferencije ili sukoba dvaju jezičnih sustava (Kassai, 1995: 106; Horga i Požgaj Hadži, 2004: 175-176). Istraživanja pokazuju da za neizvorne odrasle govornike najviše problema u izgovoru predstavljaju glasovi koji nedostaju u artikulacijskoj bazi njihova materinskoga jezika, pa se ona može promatrati kao barijera koja sprečava usvajanje određenih glasova ili obilježja glasova stranoga jezika (Menyhárt, 1999: 38-39). Zbog toga je kod govornika koji strani jezik počinju učiti u odrasloj dobi pojava akcenta gotovo neizbježna, a ovisi o njihovu materinskom jeziku, odnosno različiti jezici u kontaktu rađaju različite sustave pogrešaka (Horga i Požgaj Hadži, 2004: 176). S druge strane akcent je kod govornika stranoga jezika obično i sasvim općeprihvaćena pojava, dok se kao kriteriji dobroga izgovora navode razumljivost i prihvatljivost, te dosljednost u vlastitom izgovoru (Bárdos, 2000: 48).

\footnotetext{
${ }^{1}$ Istraživanja usmjerena na usvajanje stranih jezika govore o razvijanju komunikacijske kompetencije kod stranih govornika koja se općenito može definirati kao sve ono što govornik treba znati (jezično, pragmatično, opće, kulturološko znanje) da bi unutar jedne zajednice komunicirao na prikladan način (Medved Krajnović, 2010: 9). Prema ZEROJ-u (2005: 111) komunikacijska jezična kompetencija uključuje jezičnu, sociolingvističku i pragmatičnu komponentu, pri čemu se jezična dalje dijeli na leksičku, gramatičku, semantičku, fonološku, ortografsku i ortoepsku kompetenciju. Neka novija istraživanja pak (Pavičić Takač i Bagarić Medve, 2013) kao glavne asastavnice komunikacijske kompetencije navode jezičnu i strategijsku; jezična se dalje dijeli na gramatičku, diskursnu i pragmatičnu, dok se gramatička sastoji od morfološke i sintaktičke, leksičke te fonološke/fonetske i ortografske/ ortoepske kompetencije.
} 


\section{POUČAVANJE I USVAJANJE IZGOVORA NA SVEUČILIŠNOM STUDIJU MAĐARSKOGA KAO J2}

Mađarski jezikoslovac Bárdos $(2000,2002)$ tumači da je poučavanja izgovora u stranom jeziku smješteno negdje između dvaju mogućih pristupa koji čine suprotne polove jedne zamišljene skale: intuitivnoga i analitičkoga.

Intuitivni pristup učenju izgovora temelji se na percepciji, oponašanju i ponavljanju, a najizraženiji je kod učenja i usvajanja stranoga jezika u izvornom okruženju. Analitički pristup s druge strane u prvi plan stavlja tumačenje, prenošenje teorijskih znanja o fonološkim i fonetskim obilježjima danoga jezika koja bi se potom trebala nadopuniti uvježbavanjem pravilnoga izgovora. Poučavanje izgovora na studijima stranih jezika prvenstveno ovisi o studijskom programu, broju sati predviđenih za ovo gradivo i samim nastavnicima, a u idealnom slučaju uključuje oba spomenuta pristupa. Naime, strani lektori (koji ponekad i ne znaju jezik studenata kojima predaju) pružaju mogućnost da se studenti već na samoj nastavi susretnu s izvornim izgovornim obilježjima jezika koji uče, dok nastavnici neizvorni govornici preuzimaju zadatak prenošenja i tumačenja teorijskih znanja.

Na studiju hungarologije Filozofskog fakulteta u Zagrebu analitički pristup poučavanju izgovora sastavnim je dijelom kolegija Fonologija mađarskog jezika u drugom semestru prve godine preddiplomskoga studija. U okviru ovoga kolegija, koji izvodi nastavnik neizvorni govornik mađarskoga jezika, studenti se upoznaju s fonološkim sustavom mađarskoga jezika u usporedbi s hrvatskim, artikulacijsko-akustičkim svojstvima vokala i konsonanata, fonotaktičkim pravilima i pravilima sufiksacije, kao i glasovnim promjenama i pravopisnim načelima pri čemu se osobita pažnja posvećuje međusobnoj povezanosti pisma i izgovora (na primjer učenje novih riječi zahtijeva tumačenje istovremeno na tri međusobno povezane razine: značenjskoj, pravopisnoj i izgovornoj). Teorijska znanja nadopunjuju se uvježbavanjem izgovora onih elemenata koji se pokazuju kao poteškoća za većinu studenata, a nastoji se i da sadržaj ovoga kolegija bude vezan s gradivom na jezičnim vježbama. Nažalost, prema akreditiranom programu studija broj sati ne ostavlja dovoljno vremena za strukturiranije i temeljitije tumačenje i uvježbavanje suprasegmentalnih (prozodijskih) elemenata mađarskoga jezika, stoga je taj dio gradiva prepušten lektorima. Jezične vježbe koje studenti u velikom broju sati (tjedno osam sati na prvoj i drugoj godini, šest sati na trećoj, četiri sata na četvrtoj i petoj) slušaju tijekom studija, na prve dvije godine izvodi domaći lektor, dvojezični govornik, a od treće godine pa nadalje ugovorni lektor - izvorni govornik. 
Takva intenzivna nastava pretpostavlja komunikacijski pristup i govornu produkciju, a samim time i uočavanje i ispravljanje pogrešaka u izgovoru. Uza sva nastojanja, međutim, uočeno je da nastavni program hungarologije u cjelini znatno više pozornosti posvećuje morfologiji i sintaksi te da je fonetsko-fonološka razina neopravdano zapostavljena i često svedena na usputne korekcije.

Rad na vlastitom izgovoru - intuitivno, ali i dalje pohađajući jezične i fonetske vježbe - studenti imaju prilike nastaviti i tijekom studijskih boravaka na sveučilištima u Mađarskoj. Već i prema subjektivnoj procjeni nastavnika studenti se čak i s jednomjesečnoga boravka u izvornom okruženju (obično ljetne škole) vraćaju s boljim izgovorom, dok kod studenata koji nikada ne iskoriste mogućnost odlaska na stipendiju ispravljanje izgovornih pogrešaka teče puno sporije, izraženi akcent zadržava se do kraja studija što podupire zaključke nekih ranijih istraživanja o pozitivnom utjecaju izloženosti izvornoj okolini na usvajanje izgovora i pravilne produkcije segmenata govora koji ne postoje u materinskom jeziku govornika, čak i u odrasloj dobi (npr. Bohn i Flege, 1997).

Nije naodmet napomenuti da su tijekom studija izvornom izgovoru studenti izloženi ne samo na jezičnim vježbama kod stranoga lektora, već i na drugim kolegijima jer su nastavnici na zagrebačkoj hungarologiji u većini izvorni govornici, a od treće godine preddiplomskoga sva se nastava odvija na mađarskom jeziku.

\section{USPOREDBA MAĐARSKOGA I HRVATSKOGA FONOLOŠKOG SUSTAVA I NAJČEŠĆA IZGOVORNA ODSTUPANJA}

Premda su istraživanja posljednjih nekoliko desetljeća pokazala nedostatke primjene kontrastivne analize u procesu ovladavanja stranoga jezika (odnosno u predviđanju pogrešaka) koja svojim postavkama velikom broju izgovornih pogrešaka nije uspjela dati objašnjenje (npr. da će novi i posve drugačiji glasovi od onih u prvom jeziku biti teži za izgvovor, a slični lakši), usporedni opisi dvaju fonoloških sustava ipak mogu pomoći nastavnicima u poučavanju stranih jezika (osobito odraslih početnika na početnom stupnju). Ovdje će se kratko prikazati mađarski i hrvatski fonološki sustav i temeljene razlike među njima uz navođenje najčešćih izgovornih odstupanja.

Kada je riječ o mađarskom kao stranom jeziku, recentna stručna literatura često naglašava kako je mađarski osobito težak za učenje jer u usporedbi 
s drugim jezicima raspolaže velikim brojem vokala i konsonanata (Bóna, 2017; Gósy, 2004). U odnosu na hrvatski najveće se razlike prvenstveno odnose na vokale kojih u mađarskom ima čak četrnaest: /a/, /á/, /o/, /ó/, /u/, /ú , /ö/, /ö/, /ü/, /ü/, /e/, /é/, /i/, /í/.

Velik broj vokala mađarski zahvaljuje njihovim tvorbenim karakteristikama. Za razliku od hrvatskoga, važno obilježje mađarskih vokala jest dužina. Svi se vokali u prikazima obično dijele u sedam parova čiji se parnjaci međusobno razlikuju po kvaliteti i dužini: /a/-/á/, /e/-/é/, /i/-/í/, /o/-/ó/, $/ \mathrm{u} /-/ \mathrm{u} /, / \ddot{o} /-/ o ̋ /, / \ddot{u} /-/ \mathrm{u} /)$. Pri tome bi izgovor dugih vokala trebao biti barem 40 \% duži od kratkih (Kassai, 2005). Dužina vokala ima i razlikovnu

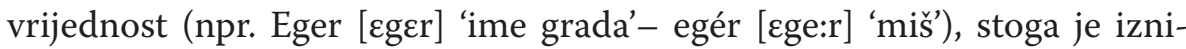
mno važno da strani govornici kratke i duge vokale nauče razlikovati kako na perceptivnoj, tako i na produkcijskoj razini. Također, u pismu je dužina vokala označena posebnim dijakritičkim znakom, što znači da nepravilan izgovor obično rezultira i pogreškama u pismu i obrnuto. Takva odstupanja naročito su česta na početnim razinama učenja, a osobito se to odnosi na kraći izgovor dugih vokala. U hrvatskom jeziku dužina kao svojstvo vokala ne postoji, kvantiteta je, uz visinu tona, prisutna u naglasku. Za razliku od složenoga sustava od četiri naglaska u hrvatskom (kratkouzlazni, kratkosilazni, dugouzlazni, dugosilazni) i njihove raspodjele, mađarski u tipološkom pogledu pripada jezicima s vezanim naglaskom, što znači da je naglasak uvijek na istom mjestu u riječi, a u slučaju mađarskoga on se bez iznimke realizira na prvom slogu (Gósy, 2004: 199). Na povezanost između pravilnoga naglašavanja riječi i dužine vokala ukazuju neka neobična izgovorna odstupanja u dvosložnim riječima koje imaju dugi vokal u slogu iza naglaska (npr. kabát [kəba:t], anyád [ə^a:d]). U takvim riječima hrvatski govornici ponekad imaju tendenciju prebacivati naglasak na drugi slog ili skraćivati izgovor dugog vokala.

Sljedeće važno obilježje mađarskih vokala je labijalnost. Svi elementi vokalskoga sustava tako se dijele na labijalne i ilabijalne: labijalni su /a/, /o/, /ó/, /u/, /ú/, /ö/, /ő/, /ü/, /ü/, a ilabilajni /á/, /e/, /é/, /i/, /í/. U hrvatskom je obilježje labijalnosti prisutno samo kod glasova /o/ i /u/. Mađarski srednji i visoki labijali /ö/, /ö/, /ü/ i /ü/ u hrvatskom jeziku nemaju svoje ekvivalente, pa bi se moglo pretpostaviti da će izgovor upravo ovih glasova biti najteže usvojiv. To međutim nije tako, naime nije primijećeno da oni predstavljaju poseban izgovorni problem za hrvatske govornike što pobija postavku kontrastivne analize prema kojoj su najteži za izgovor oni glasovi kojih nema u materinskom jeziku govornika. 
Prema kriteriju vodoravnoga položaja jezika u odnosu na tvrdo nepce mađarski se vokali dijele u dvije skupine: prednje ili palatalne /e/, /é/, /ö/, /ö/, /ü/, /ű/ i stražnje ili velarne /á/, /o/, /ó/, /u/, /ú/, a hrvatski u tri: prednji /i/, /e/, srednji /a/ i stražnji /o/, /u/. Neki autori međutim tvrde da je mađarsko dugo /á/ zapravo centralan glas (Siptár i Törkenczy, 2000) pa bi se prema tome svi vokali mogli slično hrvatskima podijeliti u tri skupine.

S obzirom na stupanj uzdignutosti jezika prema nepcu i otvorenost usne šupljine u hrvatskom razlikujemo tri skupine vokala, visoke /i/, /u/ koji su najzatvoreniji, srednje i nešto otvorenije /e/, /o/ i niski, najotvoreniji vokal /a/. Mađarski pak razlikuje četiri stupnja uzdignutosti jezika, stoga je raspodjela vokala prema tome kriteriju ovakva: visoki, zatvoreni /i/, /í/, /ü/, /ü/, /u/ i /ú/, srednji, poluzatvoreni /o/, /ó/, /ö/, /ö/ i /é/, niski, otvoreni /a/ i /e/ te najniže i najotvorenije /á/. Usporedimo li međusobno najbliže ekvivalente dvaju jezika zaključit ćemo da je hrvatsko /a/ zatvorenije od mađarskoga /á/, ali je otvorenije od mađarskoga /a/ koje je pri tom i labijalno. Hrvatsko /o/ je potom otvorenije od mađarskoga /o/, a hrvatsko /e/ zatvorenije od mađarskoga /e/. Glasovi koji se potpuno podudaraju u oba jezika samo su /i/ i /u/.

Iskustvo iz nastave govori nam da se kod hrvatskih govornika najveća odstupanja javljaju u izgovoru mađarskih kratkih vokala /a/, /e/ i njihovih dugih parnjaka /á/, i /é/. Ti su glasovi slični hrvatskim vokalima /a/ i /e/, međutim kao što je i vidljivo iz usporednoga opisa ne mogu se s njima poistovjetiti, stoga je pravilan izgovor tih glasova najteže usvojiv, a odstupanja se dugo zadržavaju (često postanu ukorijenjena i tipično obilježje stranoga izgovora).

Za razliku od vokalskih inventara, između sustava konsonanata dvaju jezika nepodudaranja su značajno manja. U mađarskom nema hrvatskih prednjenepčanih /đ/ i /dž/, dok u hrvatskom nema mađarskih nepčanih glasova /gy/ i /ty/, ali su jedni drugima najbliži ekvivalenti. Bez obzira na to, ovi mađarski glasovi ipak predstavljaju poteškoću u izgovoru pa ih pojedini studenti ne uspijevaju pravilno izgovoriti ni na višim godinama studija (najčešće se to odnosi na glas /gy/). U mađarskom postoji još i zubnik/dz/, a u hrvatskom približnik /lj/. Slično vokalima, i konsonanti mogu biti kratki i dugi (geminate) što se u pismu bilježi digramom. Geminate također imaju fonološku vrijedost (npr. tol [tol] 'gurati'- toll [tol:] 'pero, olovka') pa neadekvatno (kratko) izgovorene u početnim fazama učenja mogu dovesti do krive interpretacije značenja i poteškoćama u komunikaciji. 


\section{VAŽNOST USVAJANJA DOBROGA IZGOVORA IZ PERSPEKTIVE STUDENATA HUNGAROLOGIJE}

\subsection{Cilj istraživanja}

Kako bi se dobio bolji uvid u probleme s usvajanjem mađarskoga izgovora, u zimskom semestru akademske godine 2019./2020. provedeno je kratko istraživanje među studentima hungarologije Filozofskog fakulteta u Zagrebu. Cilj istraživanja bio je ispitati mišljenje studenata o važnosti govora i usvajanju dobroga izgovora u učenju mađarskog jezika. Također, zanimalo nas je razlikuje li se mišljenje studenata s obzirom na razinu studija (preddiplomski i diplomski studij), odnosno raste li s godinama učenja i svijest o važnosti korekcije i usavršavanja dobroga izgovora, kao i osviještenost o elementima koji predstavljaju poteškoće u usvajanju izgovora koje treba uvježbavati. Pritom su postavljene sljedeće hipoteze:

H1: Studenti diplomskoga studija bit će svjesniji važnosti usvajanja dobrog izgovora od studenata na preddiplomskom studiju.

H2: Studenti diplomskoga studija bolje će procjeniti vlastiti izgovor i vlastite pogreške od studenata preddiplomskoga studija te će shodno tomu imati i razrađenije strategije za samostalno učenje.

\subsection{Ispitanici}

Istraživanje je provedeno pomoću upitnika na uzorku od 14 studenata preddiplomskoga i 26 studenata diplomskoga studija hungarologije (četvrta, peta godina i apsolventi), izvornih govornika hrvatskoga jezika koji su mađarski počeli učiti na fakultetu kao potpuni početnici. Upitnik su ispitanici ispunjavali dobrovoljno uz potpisani pristanak i anonimno. Budući da su svi ispitanici s diplomske razine (uz izuzetak jednog) neko duže vrijeme tijekom studija proveli u izvornom jezičnom okruženju (u ljetnoj školi, na jednosemestralnoj ili dvosemestralnoj stipendiji na jednom od sveučilišta u Mađarskoj), zanimalo nas je kakva su njihova iskustva s obzirom na razumijevanje njihova govora tijekom boravka u zemlji gdje se jezik koji studiraju govori. Razina znanja ispitanika prema Zajedničkom europskom referentnom okviru (ZEROJ) na preddiplomskoj razini studija studija kretala se od A1 na prvoj godini do B1 na trećoj, a na diplomskoj razini od B1 do C1.

\subsection{Instrument}

Upitnik je u pisanom obliku imao strukturu vođenoga intervjua i sastojao se od 16 pitanja u kojima su uz ponuđene odgovore ispitanici slobodno 
mogli napisati i vlastita dodatna zapažanja. Dobiveni odgovori analizirani su kvantitativno i kvalitativno. Sva pitanja bila su grupirana u nekoliko tematskih cjelina. Pitanja iz uvodne cjeline bila su općeg tipa i odnosila su se na važnost usmene komunikacije i usvajanja izgovora na nastavi stranih jezika općenito, a potom i konkretno na nastavi jezika koji studiraju, $\mathrm{u}$ ovom slučaju mađarskoga (npr. Je li dobar izgovor/rad na dobrom izgovoru u stranom jeziku važan?). Druga cjelina sadržavala je pitanja u kojima se od studenata tražilo da sami procijene vlastiti izgovor i navedu u čemu najčešće griješe (npr. Kako procjenjujete svoj izgovor u mađarskom jeziku?). Potom se ispitivala važnost ispravljanja pogrešaka na nastavi i pojava nelagode od govora pred kolegama i nastavnicima (npr. Smatrate li važnim da nastavnici na satu ispravljaju pogreške u izgovoru? ili Osjećate li se nelagodno kad na nastavi pred kolegama trebate govoriti madarski?), iskustva diplomskih studenata u susretu s izvornim govornicima u neformalnom izvornom okruženju (npr. Jesu li vas u izvornom okruženju ikada upozorili na greške u izgovoru?) te koliko i na koji način studenti samostalno rade na svojem izgovoru (npr. Trudite li se samostalno poboljšavati svoj izgovor?). U posljednjem se pitanju od studenata pete godine i apsolvenata tražilo da na skali od 1 do 5 ocijene koliko je programom studija predviđeno (i doista ostvareno u nastavi) poučavanje govora i izgovora na mađarskom jeziku.

\subsection{Rezultati analize upitnika}

Rezultati upitnika prikazat će se tablično prema cjelinama kako je opisano u prethodnom potpoglavlju i objedinjeno za obje skupine ispitanika kako bi se jasno vidjele razlike u odgovorima.

\subsubsection{Opći dio}

Odgovori na pitanja iz općega dijela upitnika pokazuju veliku podudarnost između dviju skupina ispitanika. Studenti obje razine studija smatraju da su komunikacija i govorne vježbe, kao i rad na dobrom izgovoru važan dio nastave stranih jezika. Otprilike jedna trećina ispitanika (35 \% iz prve i 33 \% iz druge skupine) s druge strane navodi da je teško usvojiti dobar izgovor u stranom jeziku, što upućuje na to da su svjesni da će u tom procesu naići na poteškoće.

Kad je riječ konkretno o mađarskom, samo jedan ispitanik s diplomskoga studija misli da rad na dobrom izgovoru u mađarskom nije važan, dok su ostali složni u tome da jest. Isti ispitanik svoj stav pojašnjava tvrdnjom da mađarski do neke granice tolerira lošiji izgovor jer ne uzrokuje nesporazume 
u komunikaciji, ali dodaje i to da se točnim izgovorom odaje određena doza ozbiljnosti i autentičnosti. U obrazloženjima koje su mogli dati uz izabrane odgovore ukupno 12 ispitanika iz obje grupe navodi da je pravilan izgovor važan preduvjet za lakšu, bržu komunikaciju te da uvelike pridonosi tome da sugovornik točno razumije što želimo reći. Petero ispitanika smatra da upravo izgovor čini razliku u značenju, pojašnjavajući to primjerima dugih i kratkih vokala u mađarskom. Nadalje, upozoravaju na razliku u broju fonema i njihov izgovor $u$ usporedbi s hrvatskim te potrebu usvajanja pravilne proizvodnje glasova i njihova prepoznavanja. Na povezanost usvajanja pravilnoga izgovora i pravopisa upozorava četvero ispitanika, dok jedan od njih ističe važnost percepcije kao preduvjeta pravilnoga pisanja: „Na prvoj godini mi je posebno bilo važno naučiti slušati i čuti razliku u vokalima jer bi mi olakšalo pismeno izražavanje“. Četvero ispitanika nadalje navodi da je učenje i usvajanje dobroga izgovora jednako važno kao i učenje gramatike i vokabulara, dok jedan ispitanik tvrdi da je dobar izgovor u komunikaciji ponekad važniji nego gramatička točnost. Jedan ispitanik smatra da je dobar izgovor nužan u izgradnji samopouzdanja kad se radi o znanju stranoga jezika te u ostavljanju boljega dojma na sugovornika. Rapodjela postotaka po pitanjima iz ovoga dijela upitnika donosi se u Tablici 1.

Tablica 1. Opći dio

\begin{tabular}{|l|l|l|l|}
\hline Pitanja & $\begin{array}{l}\text { ponuđeni } \\
\text { odgovori }\end{array}$ & $\begin{array}{l}\text { PDS } \\
\mathbf{N}=\mathbf{1 4} \\
\text { (\%) }\end{array}$ & $\begin{array}{l}\text { DS } \\
\mathbf{N}=\mathbf{2 6} \\
\mathbf{( \% )}\end{array}$ \\
\hline $\begin{array}{l}\text { Smatrate li da je usmena komunikacija (govor) } \\
\text { važan dio nastave stranoga jezika? }\end{array}$ & $\begin{array}{l}\text { da } \\
\text { ne }\end{array}$ & $\begin{array}{l}14(100 \%) \\
0(0 \%)\end{array}$ & $\begin{array}{l}26(100 \%) \\
0(0 \%)\end{array}$ \\
\hline $\begin{array}{l}\text { Je li dobar izgovor/ rad na dobrom izgovoru u } \\
\text { stranom jeziku važan? }\end{array}$ & $\begin{array}{l}\text { da } \\
\text { ne }\end{array}$ & $\begin{array}{l}14(100 \%) \\
0(0 \%)\end{array}$ & $\begin{array}{l}25(96,15 \%) \\
1(3,84 \%)\end{array}$ \\
\hline $\begin{array}{l}\text { Smatrate li da je teško usvojiti dobar izgovor u } \\
\text { stranom jeziku? }\end{array}$ & $\begin{array}{l}\text { da } \\
\text { ne }\end{array}$ & $\begin{array}{l}9(64,28 \%) \\
5(35,71 \%)\end{array}$ & $\begin{array}{l}16(69,23 \%) \\
8(30,76 \%)\end{array}$ \\
\hline $\begin{array}{l}\text { Koliko je važan rad na dobrom izgovoru u usva- } \\
\text { janju mađarskoga jezika? }\end{array}$ & $\begin{array}{l}\text { a. uopće nije važan } \\
\text { b. nije jako važan } \\
\text { c. jako je važan }\end{array}$ & $\begin{array}{l}0(0 \%) \\
0(0 \%) \\
14(100 \%)\end{array}$ & $\begin{array}{l}0(0 \%) \\
25(96,23 \%) \\
1(3,84 \%)\end{array}$ \\
\hline
\end{tabular}

PDS = preddiplomski studij, DS = diplomski studij, $\mathrm{N}=$ broj ispitanika

\subsubsection{Samoprocjena izgovora}

Relativnu ujednačenost $\mathrm{u}$ odgovorima između dvije skupine uočavamo i u dijelu upitnika koji se odnosio na samoprocjenu izgovora (Tablica 2.). Nešto više studenata preddiplomskoga studija (10 \%) ocjenjuje svoj izgo- 
vor odličnim, dok kod starijih studenata taj postotak iznosi 7,69 \% što ipak ukazuje na to da je kritičnost prema vlastitom izgovoru podjednaka na obje razine studija.

U ovom dijelu upitnika također se željela ispitati osviještenost o elementima koji predstavljaju poteškoće u usvajanju izgovora u mađarskom jeziku. Vodeći računa o fonetsko-fonološkom sustavu mađarskoga jezika, ispitanicima je na izbor bilo ponuđeno nekoliko mogućih elemenata (naglasak riječi, rečenični naglasak i intonacija, izgovor pojedinih glasova, izgovor pojedinih skupina glasova) koje su mogli izabrati. Osim toga, ostavljena im je i mogućnost da svoje odgovore obrazlože i nadopune konkretnim primjerima. Ukupno gledajući, ispitanici s diplomskoga studija jasnije su uspjeli definirati u čemu griješe potkrepljujući to brojnim primjerima, dok su preddiplomski studenti samo zaokružili ponuđene odgovore. Pojedinačno, prema ponuđenim elementima obje grupe ispitanika navode da najviše griješe u rečeničnom naglasku i intonaciji (50 \% na preddiplomskom i $42 \%$ ispitanika na diplomskom studiju), ali ni jedni ni drugi te elemente nisu pomnije znali pojasniti na primjerima što bi se možda moglo opravdati time da ih nedovoljno razumiju. Postoci prema ostalim elementima također su podjednako raspodijeljeni. Problem s naglasakom riječi zaokružilo je 28,57 $\%$ preddiplomskih i 34,61 \% diplomskih studenata. Izgovor pojedinih glasova predstavlja problem za 21,42\% preddiplomskih i 34,61 \% diplomskih studenata. Uz taj su element ispitanici iz druge skupine dali i najviše pojašnjenja i primjera. Jedan ispitanik objašnjava da su mu u početku vokali predstavljali najveći problem jer ih u hrvatskom jeziku ima znatno manje, a $\mathrm{u}$ više odgovora navodi se pogrešan izgovor vokala koji ne postoje u hrvatskom: srednjih i visokih labijalnih glasova /ö/, /ö/, /ü/, /ű/2 , ali i niskih /a/ i /á/, kao i srednjih /e/ i /é/. Samo troje ispitanika s preddiplomskoga studija konkretno spominje da ima poteškoća s izgovorom vokala, jedan od njih navodi vokale /ö/, /ö/, a jedan /e/ i /é/. Jedan ispitanik iz ove skupine navodi da mu izgovor konsonanata /ty/ i /gy/ predstavljaju problem. Nadalje, 34,61 \% ispitanika s viših godina napominje da griješe i u izgovoru pojedinih skupina glasova te daju brojne primjere. Posebno ističu geminirane (u izgovoru duge) konsonante, kao i određene konsonantske skupine (npr. /nl/ u riječi ajánlja [əja:j:o] 'preporučiti'). Sljedovi od više konsonanata nisu česta pojava u mađarskom jer ih ograničavaju fonotaktička pravila, međutim kada se nađu jedan pored drugoga provode se jednačenja u izgovoru koja

\footnotetext{
${ }^{2}$ Izvorna govornica (lektorica) s kojom smo komentirali dobivene odgovore smatra da izgovor ovih glasova ne predstavlja posebnu poteškoću za hrvatske studente.
} 
očito predstavljaju poteškoću za studente bez obzira što se taj dio gradiva u nastavi fonologije tumači i uvježbava. Jednostavan za izgovor nije im ni slijed od više vokala u nekim oblicima do kojeg dolazi uslijed višestrukoga sufiguranja (npr. jedan od primjera koje jedan ispitanik navodi je riječ s više različitih posesivnih nastavaka könyveiéi - knjiga-posv.PL-PLposjeda-posv. PL, što bi se moglo prevesti kao 'nešto njegovih knjiga npr. stranice). Rezultati samoprocjene ispitanika donose se u Tablici 2.

Tablica 2. Samoprocjena izgovora

\begin{tabular}{|c|c|c|c|}
\hline Pitanja & ponuđeni odgovori & $\begin{array}{l}\text { PDS } \\
\qquad \begin{array}{l}N=14 \\
(\%)\end{array}\end{array}$ & $\begin{array}{l}\text { DS } \\
N=26 \\
(\%)\end{array}$ \\
\hline $\begin{array}{l}\text { Kako procjenjujete svoj izgov- } \\
\text { or u mađarskom jeziku? }\end{array}$ & $\begin{array}{l}\text { a. jako slabo } \\
\text { b. slabo } \\
\text { c. dobro } \\
\text { d. vrlo dobro } \\
\text { e. odlično }\end{array}$ & $\begin{array}{l}0(0 \%) \\
1(7,14 \%) \\
7(50 \%) \\
5(35,71 \%) \\
1(7,14 \%)\end{array}$ & $\begin{array}{l}0(0 \%) \\
7(7,69 \%) \\
14(53,84 \%) \\
8(30,76 \%) \\
2(7,69 \%)\end{array}$ \\
\hline $\begin{array}{l}\text { Možete li definirati u čemu } \\
\text { griješite? }\end{array}$ & $\begin{array}{l}\text { a. naglasak riječi } \\
\text { b. rečenični naglasak i intonacija } \\
\text { c. izgovor pojedinih glasova } \\
\text { d. izgovor pojedinih skupina glasova } \\
\text { f. bez odgovora }\end{array}$ & $\begin{array}{l}4(28,57 \%) \\
7(50 \%) \\
3(28,56 \%) \\
1(7,14 \%) \\
2(14,28 \%)\end{array}$ & $\begin{array}{l}9(34,61 \%) \\
13(42 \%) \\
9(34,61 \%) \\
9(34,62 \%) \\
-\end{array}$ \\
\hline
\end{tabular}

\subsubsection{Rad na izgovoru u nastavi}

Treća skupina pitanja čiji su odgovori prikazani u Tablici 3. odnosila se na uključenost izgovornih vježbi na nastavi i afektivne faktore koji utječu na odnos studenata prema rada na svojem izgovoru. 92,85 \% ispitanika s preddiplomskoga i 96,15 \% s diplomskoga studija smatra važnim da nastavnici na satu ispravljaju pogreške u izgovoru, dok samo po jedan ispitanik iz obje grupe smatra da to nije važan element usvajanja izgovora. Jedan ispitanik s diplomske razine svoj potvrdan odgovor nadopunjava i opaskom da bi osim na jezičnim vježbama, izgovoru više pažnje trebalo pokloniti i na drugim kolegijima tijekom studija.

Kada je riječ o afektivnim faktorima u usvajanju izgovora, 28,57 \% ispitanika preddiplomske i 23,07 \% diplomske razine osjeća nelagodu kada pred kolegama treba govoriti mađarski. Jedan ispitanik iz prve grupe to objašnjava nesigurnošću u svoje znanje, dok je iz druge skupine pet ispitanika ponudilo različita pojašnjenja. Troje od njih osjeća strah, tremu ili nelagodu kad moraju govoriti pred skupinom ljudi jer očekuju da će ih drugi osim zbog krivoga odabira riječi ili grešaka u sintaksi, osuđivati i zbog lošega 
izgovora. Jedan je odgovor usko vezan s detektiranjem elemenata koji predstavljaju poteškoće u učenju iz prethodne skupine pitanja: „u hrvatskom jeziku rečenična intonacija nije toliko naglašena kao u mađarskom, pa je potrebno na neki način i odglumiti rečeno, što je nekada na početnim godinama neugodno. Kasnije kada se usvoje osnove i izvježba izgovor, lakše je komunicirati i na samoj nastavi“. Jedan ispitanik ukazuje i na neugodnu atmosferu koja ponekad vlada na nastavi te neugodne reakcije nastavnika zbog čega se javlja strah i trema kada trebaju usmeno izraziti mišljenje o nekoj temi.

Tablica 3. Rad na izgovoru u nastavi

\begin{tabular}{|l|l|l|l|}
\hline Pitanja & $\begin{array}{l}\text { ponuđeni } \\
\text { odgovori }\end{array}$ & $\begin{array}{l}\text { PDS } \\
\mathbf{N = 1 4} \\
\mathbf{( \% )}\end{array}$ & $\begin{array}{l}\text { DS } \\
\mathbf{N}=\mathbf{2 6} \\
\mathbf{( \% )}\end{array}$ \\
\hline $\begin{array}{l}\text { Smatrate li važnim da nastavnici na satu ispravljaju } \\
\text { pogreške u izgovoru? }\end{array}$ & $\begin{array}{l}\text { da } \\
\text { ne }\end{array}$ & $\begin{array}{l}13(92,85 \%) \\
1(7,14 \%)\end{array}$ & $\begin{array}{l}25(96,15 \%) \\
1(3,84 \%)\end{array}$ \\
\hline $\begin{array}{l}\text { Osjećate li se nelagodno kad na nastavi pred kolegama } \\
\text { trebate govoriti mađarski? }\end{array}$ & $\begin{array}{l}\text { da } \\
\text { ne }\end{array}$ & $\begin{array}{l}4(28,57 \%) \\
10(71,42 \%)\end{array}$ & $\begin{array}{l}20(23,07 \%) \\
6(79,92 \%)\end{array}$ \\
\hline
\end{tabular}

\subsubsection{Izvorno okruženje}

Sljedeća skupina pitanja postavljena je samo ispitanicima s diplomske razine studija hungarologije, a tiče se iskustava stečenih tijekom stipendijskih boravaka u izvornom okruženju. Kao što pokazuje Tablica 4. na greške u izgovoru izvorni su govornici mađarskoga jezika upozorili nešto manje od polovice naših ispitanika, dok ostali nisu imali to iskustvo. Poteškoće u komunikaciji zbog izgovora potvrdilo je $26,92 \%$ ispitanika, za ostale izgovor nije igrao ulogu u uspješnosti komunikacije u mađarskom jezičnom okruženju niti su imali većih poteškoća u komunikaciji. Uspoređujući odgovore na pitanja je li im neugodno kad trebaju na nastavi govoriti pred kolegama (iz Tablice 3.) i pred izvornim govornicima, zaključujemo da studentima veći problem predstavljaju kolege i nastavnici, nego izvorni govornici. Pojedini ispitanici ovako tumače ovu pojavu: „izvorni govornici često imaju više razumijevanja i sretni su što se netko potrudio naučiti njihov jezik pa i ne očekuju savršeno znanje jezika“ ili u „neformalnom okruženju bitno je samo da sam voljna komunicirati sa ljudima - to više cijene, te ne brinu o usputnim greškama“. Međutim, razlog nelagode kad trebaju kominicirati na mađarskom može biti i osobne prirode (npr. perfekcionizam u učenju jezika): „neugodno mi je zato što imam dojam da mi vokabular nikad neće biti dovoljno širok da bih normalno razgovarao s izvornim govornikom" ili 
„jako mi je neugodno, do te mjere da sve drugo (gramatiku) pokvarim jer razmišljam o tome kako ne zvučim dovoljno mađarski“. Sve to nam govori da na nastavi valja svakako uzeti u obzir i individualne osobine govornika te nastojati na postizanju ugodne i tolerantne atmosfere.

Tablica 4. Izvorno okruženje

\begin{tabular}{|c|c|c|}
\hline Pitanja & $\begin{array}{l}\text { ponuđeni } \\
\text { odgovori }\end{array}$ & $\begin{array}{l}\text { DS } \\
N=26 \\
(\%)\end{array}$ \\
\hline $\begin{array}{l}\text { Osjećate li se nelagodno kad pred izvornim govornicima u } \\
\text { neformalnom okruženju govorite mađarski? }\end{array}$ & $\begin{array}{l}\text { da } \\
\text { ne }\end{array}$ & $\begin{array}{l}9(34,65 \%) \\
17(65,38 \%)\end{array}$ \\
\hline Jesu li vas u izvornom okruženju ikada upozorili na greške u izgovoru? & $\begin{array}{l}\text { da } \\
\text { ne }\end{array}$ & $\begin{array}{l}12(46,15 \%) \\
14(53,84 \%)\end{array}$ \\
\hline $\begin{array}{l}\text { Jeste li imali poteškoća u komunikaciji u izvornom okruženju zbog } \\
\text { svojeg izgovora? }\end{array}$ & $\begin{array}{l}\text { da } \\
\text { ne }\end{array}$ & $\begin{array}{l}7(26,92 \%) \\
19(73,07 \%)\end{array}$ \\
\hline
\end{tabular}

\subsubsection{Samostalan rad na izgovoru}

Odgovori iz dijela upitnika o samostalnom radu na izgovoru pokazuju da se studenti diplomskoga studija više trude samostalno poboljšavati i ispravjljati svoj izgovor od ispitanika s preddiplomske razine, i to na različite načine: gledanje mađarskih filmova, serija i slušanje radija ili različitih audiomaterijala za učenje mađarskoga kao stranog jezika, komunikacija s izvornim govornicima (pri čemu pažnju usmjeravaju na slušanje i oponašanje izgovora pojedinih riječi), čitanje naglas i višestruko izgovaranje i ponavljanje riječi ili glasova koji im predstavljaju poteškoću u izgovoru. Neki priznaju da nemaju nikakvu posebnu metodu učenja, ali se nastoje ispraviti ako primijete da su nešto krivo izgovorili. Značajan postotak $(28,57$ \%) ispitanika s preddiplomskoga studija priznaje da se uopće ne trudi poboljšati svoj izgovor, što je neobično jer se nitko od ispitanika ne slaže s tvrdnjom da nije potrebno raditi na dobrom izgovoru jer se ionako ne možemo približiti izgovoru izvornoga govornika. Također se svi slažu da izvorno okruženje pomaže u usvajanju izgovora.

U pitanju gdje je trebalo navesti razloge zašto usavršavati izgovor bilo je moguće zaokružiti više ponuđenih odgovora, ali i nadopuniti ih vlastitim zapažanjima. Uočavamo da obje skupine ispitanika najčešće navode da je to nužno radi buduće struke i posla (78,57 \% i 73,07 \%). Na preddiplomskoj razini potom slijedi perfekcionizam $(42,85 \%)$ koji je diplomskoj razini na posljednjem mjestu (23,07 \%). Među diplomskim studentima kao važan razlog javlja se stvaranje boljega dojma koji dobrim izgovorom ostavljamo 
na sugovornika (43,30 \%), dok značajan broj njih smatra da će nam zbog dobroga izgovora biti toleriran pokoji gramatički i leksički lapsus (30,76 \%). Pojedini ispitanici s diplomske razine još jednom ponavljaju svoj stav o važnosti izgovora u ukupnom svladavanju nekog jezika, dok jedan ispitanik jasno razdvaja različite potrebe i ambicije u svladavanju izgovora navodeći da bi u struci, kao što je primjerice simultano i konsekutivno prevođenje gdje je važna komunikacija, izgovor naravno trebao biti bolji, a ako je riječ o pismenom prevođenju, osoba može obavljati taj posao i bez savršenoga izgovora.

Skupni podaci koji se odnose na pitanja vezana uz samostalan rad na izgovoru i razlozima usavršavanja izgovora prikazani su u Tablici 5.

Tablica 5. Samostalan rad na izgovoru

\begin{tabular}{|c|c|c|c|}
\hline Pitanja & ponuđeni odgovori & $\begin{array}{l}\text { PDS } \\
\qquad \begin{array}{l}N=14 \\
(\%)\end{array}\end{array}$ & $\begin{array}{l}\text { DS } \\
N=26 \\
(\%)\end{array}$ \\
\hline $\begin{array}{l}\text { Trudite li se samostalno poboljšavati svoj } \\
\text { izgovor? }\end{array}$ & $\begin{array}{l}\text { da } \\
\text { ne }\end{array}$ & $\begin{array}{l}10(71,42 \%) \\
4(28,57 \%)\end{array}$ & $\begin{array}{l}25(96,15 \%) \\
1(3,84 \%)\end{array}$ \\
\hline $\begin{array}{l}\text { Izvorno jezično okruženje pomaže u } \\
\text { usvajanju izgovora. }\end{array}$ & $\begin{array}{l}\text { da } \\
\text { ne }\end{array}$ & $14(100 \%)$ & $26(100 \%)$ \\
\hline $\begin{array}{l}\text { Nije potrebno raditi na dobrom izgovoru } \\
\text { jer se ionako ne možemo približiti } \\
\text { izgovoru materinskoga govornika. }\end{array}$ & $\begin{array}{l}\text { da } \\
\text { ne }\end{array}$ & $14(100 \%)$ & $26(100 \%)$ \\
\hline Zašto vrijedi usavršavati izgovor? & $\begin{array}{l}\text { a. bolji dojam } \\
\text { b. dobar izgovor prikriva } \\
\text { gramatičke pogreške } \\
\text { c. struka, budući posao } \\
\text { d. perfekcionizam } \\
\text { e. nešto drugo }\end{array}$ & $\begin{array}{l}5(35,71 \%) \\
4(28,57 \%) \\
11(78,57 \%) \\
6(42,85 \%) \\
1(7,14 \%)\end{array}$ & $\begin{array}{l}11(42,30 \%) \\
8(30,76 \%) \\
19(73,07 \%) \\
6(23,07 \%) \\
8(30,76 \%)\end{array}$ \\
\hline
\end{tabular}

\subsubsection{Ocjena studijskoga programa}

U posljednjem pitanju iz upitnika od ispitanika završne, pete godine studija i apsolvenata tražilo se da na skali od 1 do 5 (na kojoj je broj 1 označavao da se govor i izgovor uopće ne poučavaju, a broj 5 da se poučavaju u punoj mjeri) procijene koliko je studijskim programom predviđeno i ostvareno $\mathrm{u}$ nastavi poučavanje govora i izgovora na studiju hungarologije (Tablica 6.). Vrijednosti 3 i 4 dobile su po 47,36 \% odgovora, dok se 5,23 \% ispitanika opredijelilo za vrijednost 2 (jedan ispitanik na ovo pitanje nije dao odgovor). Ova ocjena potvrđuje ranije istaknutu tezu: premda se rad na izgovoru i izgovorne vježbe nastoji uključiti u pojedine jezične kolegije na studiju, 
čini se da potrebno njihovo sustavnije provođenje s razrađenijim planom rada.

Tablica 6. Ocjena studijskog programa

\begin{tabular}{|c|c|c|}
\hline Pitanja & $\begin{array}{l}\text { ponuđeni } \\
\text { odgovori }\end{array}$ & $\begin{array}{l}\text { DS } \\
N=26 \\
(\%)\end{array}$ \\
\hline $\begin{array}{l}\text { Ocijenite na skali od } 1 \text { do } 5 \text { koliko je programom studija } \\
\text { predviđeno (i doista ostvareno u nastavi) poučavanje govora i } \\
\text { izgovora na mađarskom jeziku }\end{array}$ & $\begin{array}{l}1 \\
2 \\
3 \\
4 \\
5 \\
\text { bez odgovora }\end{array}$ & $\begin{array}{l}- \\
1(5,23 \%) \\
12(47,36 \%) \\
12(47,36 \%) \\
- \\
1(5,23 \%)\end{array}$ \\
\hline
\end{tabular}

\section{ZAKLJUČNE NAPOMENE}

Unatoč tomu što se kao odrasli početnici teško mogu približiti izgovoru izvornih govornika mađarskoga jezika, rezultati istraživanja pokazuju da je razina osviještenosti studenata hungarologije o važnosti poučavanja izgovora, kao i samostalnoga rada na dobrom izgovoru tijekom studija vrlo visoka na obje razine studija, stoga se hipoteza da će studenti diplomskoga studija općenito biti svjesniji važnosti dobroga izgovora nije potvrdila. Velika podudarnost $\mathrm{u}$ odgovorima između dvije skupine ispitanika mogla bi se objasniti malim uzorkom ispitanika s preddiplomskoga studija pa bi za točnije rezultate $u$ istraživanje treblo uključiti još studenata $s$ te razine.

Ipak, neki odgovori u drugom dijelu upitnika koji se odnosio konkretno na mađarski jezik pokazuju nepodudarnosti u odgovorima između dvije skupine i veću svijest o važnosti korekcije i samostalnoga usavršavanja dobroga izgovora kod diplomskih studenata. Oni su u pitanjima gdje su se tražile nadopune odgovorima dali opširnija i detaljnija objašnjenja, dobro uočavaju vlastite pogreške koje se u načelu poklapaju s navedenim odstupanjima koje su u praktičnoj nastavi primijetili nastavnici, a koja su spomenuta u 4. poglavlju (izgovor kratkih vokala /a/, /e/ i njihovih dugih parnjaka /á/, i /é/, konsonanti /ty/ i /gy/). Osim toga, više se trude na usavršavanju izgovora, imaju razrađenije strategije za samostalno učenje te su shodno tomu i kritičniji prema vlastitom izgovoru čime je potvrđena naša druga hipoteza.

Važan je i podatak da svi podjednako osjećaju nelagodu kad trebaju na nastavi pred kolegama i nastavnikom govoriti na mađarskom jeziku. Osim osobnih razloga tomu može biti uzrok i nelagodna atmosfera u učionici, 
kao i stav samog nastavnika. Odgovori ukazuju na to da su izvorni govornici u izvornom okruženju često tolerantniji na pogreške u izgovoru i strpljiviji u komunikaciji sa strancima. Ovo su faktori koji igraju važnu ulogu u motivaciji studenata za učenje mađarskoga jezika, stoga bi ih trebalo osvijestiti i kod nastavnika.

Spoznaje dobivene ovim upitnikom osim što su vrijedan putokaz u poučavanju i podizanju svijesti o važnosti rada na dobrom izgovoru kod studenata, mogu poslužiti i kao polažište za nova istraživanja. Smatramo da bi bilo vrijedno detaljnije ispitati gubi li se strani akcent $s$ godinama učenja i boravkom u izvornom okruženju, mogu li se iz usporednih opisa uistinu pretpostaviti eventualne poteškoće i pogreške ili su tendencije drugačije, kakva je uloga afektivnih faktora u usvajanju izgovora i dr. Jako važno, osim toga, bilo bi što točnije opisati i klasificirati izgovorna odstupanja prema razinama učenja kako bi ih se moglo sustavnije otklanjati, što do sada nije učinjeno. To bi pomoglo i u osmišljavanju i izradi novoga ili poboljšanju postojećega studijskog programa. Da je to prijeko potrebno jasno pokazuje i srednja prosječna ocjena koju su programu dali sami studenti. Jedan od mogućih prijedloga organizacije nastave fonetike na studijima hunagrologije moglo bi biti izdvajanje izgovornih vježbe kao zasebnoga kolegija koji bi se izvodio kroz dva semestra po jedan sat tjedno na višim godinama preddiplomskoga studija kad studenti već raspolažu temeljnim jezičnim znanjima te se mogu lakše usredotočiti na izgovor. Tako bi se za razliku od sadašnjega programa u kojem je taj dio gradiva integriran u nastavu fonologije na prvoj godini te jezičnih vježbi gdje su mu često pretpostavljeni drugi sadržaji, veća pažnja mogla pokloniti uvježbavanju i korekciji proizvodnje i percepcije glasova, prepoznavanju izgovornih razlika unutar skupina glasova, mogle bi se osvijestiti i razlike između hrvatskih i mađarskih glasovnih sustava, a prostor bi dobili i suprasegmentalni i prozodjski jezični elementi za koje studenti tvrde da predstavljaju poteškoću u učenju. Na temelju stečenih spoznaja i praktičnih znanja studenti bi kasnije bili spremni(ji) za samostalan rad na vlastitom izgovoru i, ono što je najvažnije, sigurniji u svoju govornu produkciju.

\section{LITERATURA}

Bárdos, J. (2000) Az idegen nyelvek tanitásának elméleti alapjai és gyakorlata. Budapest: Nemzeti Tankönyvkiadó.

Bárdos, J. (2002) A kiejtés fontossága és pontossága. Nyelvpedagógia. Pécs: Iskolakultúra, 139-152. 
Bohn, O. i Flege, J. E. (1997) Perception and production of new vowel category by adult second language learners. Second-Language Speech. 53-73.

Bóna, J. (2017) A szupraszegmentális hangszerkezet szerepe az akcentus megítélésében. THL2, 217-225.

Gósy, M. (2004) Fonetika, a beszéd tudománya. Budapest: Osiris Kiadó.

Horga, D. i Požgaj Hadži, V. (2004) Govorna fluentnost u stranom jeziku: hrvatski i slovenski. U Stolac, D. i sur. (ur.) Suvremena kretanja u nastavi stranih jezika. Zagreb, Rijeka. 175-185.

Kassai, I. (1995) Pszicho-szociolingvisztikai jegyzetek az akcentusról. Általános Nyelvészeti Tanulmányok 18, 103-115.

Kasssai, I. (2005) Fonetika. Budapest: Nemzeti Tankönyvkiadó.

M. Korchmáros, V. (2006) Lépesenként nagyarul. Magyar nyelvtani kézikönyv. Szegedi Tudomány Egyetem. Hungarológiai Központ.

Markó, A. (2004) A magyar nyelv szupraszengmentális jellemzőinek tanítása - problámák és lehetőségek. Hungarológiai Évkönyv, 5 (1), 125-136.

Medved Krajnović, M. (2010) Od jednojezičnosti do višejezičnosti. Uvod u istraživanja procesa ovladavanja inim jezikom. Zagreb: Leykam.

Menyhárt, K. (1999) Szláv anyanyelvűek magyar beszédének fonetikai sajátosságai. Beszédkutatás 1999. 30-44.

Pavičić Takač, V. i Bagarić Medve, V. (2013) Jezična i strategijska kompetencija u stranome jeziku. Osijek: Filozofski fakultet Sveučilišta J. J. Strossmayera u Osijeku.

Siptár, P. (1994) Megjegyzések a magyar magánhangzó-állományról. Beszédkutatás. 1994. 81-93.

Siptár, P. i Törkenczy, M. (2000) The Phonology of Hungarian. Oxford University Press.

Szende, V. (2006) Szupraszengmentális deviánciák a magyart mint idegen nyelvként tanulók mondat nagyságrendü közléseiben. THL2, 1-2. 72-85.

Vijeće za kulturnu suradnju, Odbor za obrazovanje, Odjel za suvremene jezike, Strasbourg (2005) Zajednički europski referentni okvir za jezike: učenje, poučavanje, vrednovanje. Zagreb: Školska knjiga. (Prijevod: Bressan V i Horvat, M.). 


\title{
Students' assessment of the importance of acquiring proper pronunciation of Hungarian as a foreign language
}

\author{
Kristina Katalinić \\ kkatalin@ffzg.hr \\ Faculty of Humanities and Social Sciences, University of Zagreb
}

\begin{abstract}
Studying and acquiring proper pronunciation in philological studies primarily depends on the study programme itself, the number of lessons foreseen for language exercises and other language courses, as well as on the competence of the teachers who teach in that study programme. This paper aims to illustrate how much, in addition to imparting theoretical knowledge within the Hungarian Studies Programme at the Faculty of Humanities and Social Sciences in Zagreb, practical exercises for proper pronunciation are taught, within the framework of which courses, and in what way. Furthermore, the phonological features of the Hungarian language shall be briefly presented in comparison to the Croatian language, with an emphasis on elements which represent challenges for adult beginners in pronunciation acquisition. In the third part of the paper, the results of a study conducted among the students of Hungarian Studies shall be presented. This study was aimed at examining the importance of proper pronunciation in acquiring Hungarian as a foreign language from their perspective in order to obtain potential guidelines for improving the existing study programme and creating a new one.
\end{abstract}

Key words: Hungarian as a second language, speech production, pronunciation teaching and acquisition, pronunciation errors, self-assessment. 